\title{
Effect of Plant Growth Regulators on Nitrate Reductase Activity in Seed Guar Varieties
}

\author{
M. Tagore Naik, D. Srihari, A.V.D. Dorajeerao*, K. Sasikala, \\ K. Umakrishna and D.R.S. Suneetha
}

Horticultural Research Station, Mahanandi, College of Horticulture, Venkataramannagudem (Andhra Pradesh), India

*Corresponding author

\section{A B S T R A C T}

Keywords

Plant growth regulators, Nitrate reductase activity and seed guar

Article Info

Accepted:

26 October 2018

Available Online:

10 November 2018
The effect of growth regulator on growth and flowering of seed guar cultivars viz., HG 365 and HG 563 was analysed under Mahanandi conditions. The highest nitrate reductase activity, crude protein and gum content was recorded by HG 365 cultivar whereas the growth regulators found maximum in nitrate reductase activity and crude protein was recorded by the application of CCC at $1500 \mathrm{ppm}$ which was on par with CCC $1000 \mathrm{ppm}$. The cultivar HG 365 exhibited the highest gum content and among the growth regulators sprays, CCC at 1500 ppm exhibited the highest gum content being the one having the bold sized seeds. The sprays of CCC and triacontanol at $1500 \mathrm{ppm}$ were found on par with 1000 ppm, thus making the effect of additional amount of chemicals non-significant in increasing gum content of individual seeds.

\section{Introduction}

Cluster bean is botanically called as Cyamopsis tetragonoloba (L.) Taub. It belongs to the family Leguminaceae. The crop is popularly known as guar referring to its seed. India is considered as native place for guar or cluster bean. Guar tolerates high temperature and dry conditions, thus gaining popularity in arid and semi-arid climates (Undersander et al., 2006). It has been used as vegetable in our country from hundreds of years. India exported about 406,312 MT of guar products to the world valued at about US\$4 billion. In fact, guar products became the largest agricultural export item in 2012-13, surpassing basmati rice. These developments have opened up immense opportunities for many key stakeholders involved in the production, consumption and trade of guar products (Durgesh, 2015).

Studies on varietal suitability have been initiated at different research centers, and their preliminary results pointed out the merit of certain varieties viz., HG-563 and HG-365 (Prasanthi and Krishna, 2012). Plant growth regulators (PGRs) are known to improve physiological efficiency including photosynthetic ability of plants and offer a significant role in realizing higher crop yields. The PGRs are known to influence the sourcesink relationship and stimulate the translocation of photosynthetic assimilates, 
thereby increasing the productivity in various crops (Prabhavathi, 2005). Application of growth regulators also increase flower, fruit setting, grain filling and test weight in different crops where seed is economic product (Patel and Singh, 1980), Certain growth regulating chemicals like triacontanol are known to influence photosynthesis, nutrient uptake, enzymatic activity and gene regulation and is proved to be beneficial in various crops (Haleh and Ergin, 2010). Though, the plant growth regulators have great potential, their application has to be judiciously planned in terms of optimal concentration.

\section{Materials and Methods}

The experiment was conducted in factorial randomized design with two factors viz., varieties (2) and growth regulator (3) at each at 3 concentrations replicated thrice. The plot was laid out at Horticultural Research Station, Mahanandi, Kurnool district of Andhra Pradesh during both kharif and rabi seasons of the years 2014-15 and 2015-16. The data obtained on various characters were statistically analyzed in factorial randomized block design as described by Panse and Sukhatme (1985). The treatment means were tested for their significant difference by calculating critical difference values at 5\% level of significance.

\section{Results and Discussion}

Nitrate reductase activity ( $\mu$ moles $\mathrm{NO}_{2} \mathrm{~g}$ fresh weight ${ }^{-1} \mathrm{hr}^{-1}$ )

The nitrate reductase activity (Table 1) differed significantly due to spray of growth regulators during kharif and rabi seasons. At 60 DAS, the highest nitrate reductase activity (kharif 77.96; rabi 71.72) was recorded by HG 365. Among the growth regulators, maximum nitrate reductase activity (kharif 79.58 ; rabi
73.21) was recorded by the application of $\mathrm{CCC}$ at $1500 \mathrm{ppm}$ which was on par with CCC 1000 ppm (kharif 79.15; rabi 72.82). The lowest nitrate reductase activity was observed by the spray of MC 500 ppm (kharif 69.03; rabi 63.50) preceded by MC 1000 ppm (kharif 73.74; rabi 67.84). TRIA 1500 ppm resulted in the medium activity of nitrate reductase enzyme (kharif 78.63; rabi 72.34). The control recorded a nitrate reductase activity of 68.39 in kharif and 62.92 in rabi at 60 DAS.

\section{Crude protein (\%)}

The crude protein (\%) (Table 2) differed significantly due to spray of growth regulators during kharif and rabi seasons. The highest crude protein (kharif 26.41; rabi 24.29) was recorded by $\mathrm{HG}$ 365. Among the growth regulators, maximum crude protein (kharif 25.71; rabi 23.65) was recorded by the application of CCC at 1500 ppm which was on par with CCC 1000 ppm (kharif 25.59; rabi 23.54). The lowest crude protein was observed by the spray of MC $500 \mathrm{ppm}$ (kharif 23.71; rabi 21.82) which was on par with MC 1000 ppm (kharif 23.95; rabi 22.03). Application of TRIA 1500 ppm resulted in the moderate value during both the seasons (kharif 25.24, rabi 23.22). The control recorded a crude protein of $23.48 \mathrm{~g}$ in kharif and 21.60 in rabi. It is inferred from the results on nitrate reducase activity and crude protein that both of them were dependent or associated together. Higher the nitrate reductase activity higher was the crude protein content and vice versa. Thus in the present study both these values were recorded at maximum level by the variety HG 365 and the spray of CCC at 1500 ppm. The enzyme nitrate reductase helps in the assimilation of nitrate nitrogen into the plants and therefore it might help in higher nitrogen content in various plant parts making it available for the biosynthesis of protein molecules. 
Table.1 Nitrate reductase activity $(\mu$ moles NO2 g fresh weight-1 hr-1) at 60 DAS as influenced by growth regulators in cluster bean varieties during kharif and rabi 2015-16

\begin{tabular}{|c|c|c|c|c|c|c|}
\hline \multirow{3}{*}{$\begin{array}{l}\text { Growth regulators (ppm) } \\
\text { (B) }\end{array}$} & \multicolumn{6}{|c|}{ Variety (A) } \\
\hline & \multicolumn{3}{|c|}{ Kharif } & \multicolumn{3}{|c|}{ Rabi } \\
\hline & HG 365 & HG 563 & Mean & HG 365 & HG 563 & Mean \\
\hline CCC 500 & 77.55 & 71.35 & 74.45 & 71.35 & 65.64 & 68.49 \\
\hline CCC 1000 & 82.45 & 75.85 & 79.15 & 75.85 & 69.78 & 72.82 \\
\hline CCC 1500 & 82.89 & 76.26 & 79.58 & 76.26 & 70.16 & 73.21 \\
\hline MC 500 & 71.90 & 66.15 & 69.03 & 66.15 & 60.86 & 63.50 \\
\hline MC 1000 & 76.81 & 70.67 & 73.74 & 70.67 & 65.02 & 67.84 \\
\hline MC 1500 & 76.99 & 70.83 & 73.91 & 70.83 & 65.16 & 67.99 \\
\hline TRIA 500 & 76.55 & 70.42 & 73.49 & 70.42 & 64.79 & 67.61 \\
\hline TRIA 1000 & 81.30 & 74.80 & 78.05 & 74.80 & 68.82 & 71.81 \\
\hline TRIA 1500 & 81.91 & 75.36 & 78.63 & 75.36 & 69.33 & 72.34 \\
\hline Control & 71.24 & 65.54 & 68.39 & 65.54 & 60.29 & 62.92 \\
\hline Mean & 77.96 & 71.72 & 74.84 & 71.72 & 65.98 & 68.85 \\
\hline Factor & $S E m \pm$ & & & $S E m \pm$ & & \\
\hline Variety $(A)$ & 0.054 & & & 0.049 & & \\
\hline Growth regulators $(B)$ & 0.268 & & & 0.246 & & \\
\hline Interaction $(A x \quad B)$ & - & & & - & & \\
\hline
\end{tabular}

CD: CD at 5\% level of significance; DAS: Days after sowing; CCC: Cycocel; MC: Mepiquat chloride; TRIA: Triacontanol 
Table. 2 Crude protein (\%) as influenced by growth regulators in cluster bean varieties during kharif and rabi 2015-16

\begin{tabular}{|c|c|c|c|c|c|c|}
\hline \multirow{3}{*}{$\begin{array}{l}\text { Growth regulators (ppm) } \\
\text { (B) }\end{array}$} & \multicolumn{6}{|c|}{ Variety (A) } \\
\hline & \multicolumn{3}{|c|}{ Kharif } & \multicolumn{3}{|c|}{$R a b i$} \\
\hline & HG 365 & HG 563 & Mean & HG 365 & HG 563 & Mean \\
\hline CCC 500 & 27.11 & 23.60 & 25.36 & 24.94 & 21.71 & 23.33 \\
\hline CCC 1000 & 27.36 & 23.82 & 25.59 & 25.17 & 21.91 & 23.54 \\
\hline CCC 1500 & 27.49 & 23.93 & 25.71 & 25.29 & 22.01 & 23.65 \\
\hline MC 500 & 25.35 & 22.07 & 23.71 & 23.32 & 20.31 & 21.82 \\
\hline MC 1000 & 25.60 & 22.29 & 23.95 & 23.56 & 20.51 & 22.03 \\
\hline MC 1500 & 25.86 & 22.51 & 24.18 & 23.79 & 20.71 & 22.25 \\
\hline TRIA 500 & 26.36 & 22.95 & 24.65 & 24.25 & 21.11 & 22.68 \\
\hline TRIA 1000 & 26.86 & 23.38 & 25.12 & 24.71 & 21.51 & 23.11 \\
\hline TRIA 1500 & 26.98 & 23.49 & 25.24 & 24.83 & 21.61 & 23.22 \\
\hline Control & 25.10 & 21.85 & 23.48 & 23.09 & 20.10 & 21.60 \\
\hline Mean & 26.41 & 22.99 & 24.70 & 24.29 & 21.15 & 22.72 \\
\hline Factor & $S E m \pm$ & \multicolumn{2}{|c|}{$C D$} & $S E m_{ \pm}$ & \multicolumn{2}{|c|}{$C D$} \\
\hline Variety $(A)$ & 0.011 & \multicolumn{2}{|c|}{0.03} & 0.010 & \multicolumn{2}{|c|}{0.03} \\
\hline Growth regulators $(B)$ & 0.054 & \multicolumn{2}{|c|}{0.16} & 0.050 & \multicolumn{2}{|c|}{0.15} \\
\hline Interaction $(A x B)$ & - & \multicolumn{2}{|c|}{$N S$} & - & \multicolumn{2}{|c|}{$N S$} \\
\hline
\end{tabular}

CD: CD at 5\% level of significance; CCC: Cycocel; MC: Mepiquat chloride; TRIA: Triacontanol 
Table.3 Crude gum (\%) as influenced by growth regulators in cluster bean varieties during kharif and rabi 2015-16

\begin{tabular}{|c|c|c|c|c|c|c|}
\hline \multirow[t]{3}{*}{ Growth regulators (B) } & \multicolumn{6}{|c|}{ Variety (A) } \\
\hline & \multicolumn{3}{|c|}{ Kharif } & \multicolumn{3}{|c|}{$R a b i$} \\
\hline & HG 365 & HG 563 & Mean & HG 365 & HG 563 & Mean \\
\hline CCC 500 & 31.97 & 29.98 & 30.98 & 29.69 & 28.00 & 28.85 \\
\hline CCC 1000 & 32.23 & 30.21 & 31.22 & 29.93 & 28.21 & 29.07 \\
\hline CCC 1500 & 32.36 & 30.33 & 31.35 & 30.05 & 28.32 & 29.19 \\
\hline MC 500 & 30.12 & 28.38 & 29.25 & 27.99 & 26.52 & 27.26 \\
\hline MC 1000 & 30.38 & 28.60 & 29.49 & 28.23 & 26.73 & 27.48 \\
\hline MC 1500 & 30.65 & 28.83 & 29.74 & 28.48 & 26.94 & 27.71 \\
\hline TRIA 500 & 31.18 & 29.29 & 30.24 & 28.96 & 27.37 & 28.17 \\
\hline TRIA 1000 & 31.70 & 29.75 & 30.73 & 29.45 & 27.79 & 28.62 \\
\hline TRIA 1500 & 31.83 & 29.87 & 30.85 & 29.57 & 27.89 & 28.73 \\
\hline Control & 31.38 & 29.47 & 30.43 & 29.15 & 27.53 & 28.34 \\
\hline Mean & 31.97 & 29.98 & 30.98 & 29.69 & 28.00 & 28.85 \\
\hline Factor & $S E m \pm$ & \multicolumn{2}{|c|}{ CD at $5 \%$} & $S E m \pm$ & \multicolumn{2}{|c|}{$C D$ at $5 \%$} \\
\hline Variety $(A)$ & 0.011 & \multicolumn{2}{|c|}{0.03} & 0.011 & \multicolumn{2}{|c|}{0.03} \\
\hline Growth regulators $(B)$ & 0.057 & \multicolumn{2}{|c|}{0.17} & 0.053 & \multicolumn{2}{|c|}{0.15} \\
\hline Interaction $\left(\begin{array}{lll}A & x & B\end{array}\right)$ & - & \multicolumn{2}{|c|}{$N S$} & - & \multicolumn{2}{|c|}{$N S$} \\
\hline
\end{tabular}

CD: CD at 5\% level of significance; CCC: Cycocel; MC: Mepiquat chloride; TRIA: Triacontanol 
Table.4 Seed yield per plant (g) as influenced by growth regulators in cluster bean varieties during kharif and rabi 2015-16

\begin{tabular}{|c|c|c|c|c|c|c|}
\hline \multirow[t]{3}{*}{ Growth regulators (B) } & \multicolumn{6}{|c|}{ Variety (A) } \\
\hline & \multicolumn{3}{|c|}{ Kharif } & \multicolumn{3}{|c|}{ Rabi } \\
\hline & HG 365 & HG 563 & Mean & HG 365 & HG 563 & Mean \\
\hline CCC 500 & 17.55 & 15.78 & 16.67 & 16.67 & 14.99 & 15.83 \\
\hline CCC 1000 & 19.01 & 17.10 & 18.05 & 18.06 & 16.24 & 17.15 \\
\hline CCC 1500 & 19.30 & 17.36 & 18.33 & 18.34 & 16.49 & 17.42 \\
\hline MC 500 & 15.35 & 13.81 & 14.58 & 14.59 & 13.12 & 13.85 \\
\hline MC 1000 & 15.72 & 14.14 & 14.93 & 14.93 & 13.43 & 14.18 \\
\hline MC 1500 & 15.79 & 14.20 & 15.00 & 15.00 & 13.49 & 14.25 \\
\hline TRIA 500 & 16.09 & 14.47 & 15.28 & 15.28 & 13.74 & 14.51 \\
\hline TRIA 1000 & 17.55 & 15.78 & 16.67 & 16.67 & 14.99 & 15.83 \\
\hline TRIA 1500 & 17.84 & 16.05 & 16.94 & 16.95 & 15.24 & 16.10 \\
\hline Control & 14.62 & 12.78 & 13.70 & 13.89 & 12.14 & 13.01 \\
\hline Mean & 16.88 & 15.15 & 16.01 & 16.04 & 14.39 & 15.21 \\
\hline Factor & $S E m \pm$ & $C$ & & $S E m \pm$ & & \\
\hline Variety $(A)$ & 0.02 & 0. & & 0.02 & 0. & \\
\hline Growth regulators $(B)$ & 0.10 & 0. & & 0.10 & 0. & \\
\hline Interaction $\left(\begin{array}{lll}A & x & B\end{array}\right)$ & 0.12 & 0. & & 0.11 & 0. & \\
\hline
\end{tabular}

CD: CD at 5\% level of significance; CCC: Cycocel; MC: Mepiquat chloride; TRIA: Triacontanol 
This might be the reason as to why a higher activity of nitrate reductase as observed in the best combination of treatments of growth regulator spray had led to a higher content of crude protein. However, it was observed that both the activity of enzyme and content of protein did not increase significantly with increase in the concentration of growth regulators spray beyond $1000 \mathrm{ppm}$ thus making the effect of additional amount of chemical null and void in majority of the cases.

However, the additional dose of chemical was found beneficial across the other growth regulators. In other words the highest concentration of CCC was significantly superior to the highest concentration of triacontanol which was on par with the lowest concentration of CCC. However, the highest concentration of mepiquat chloride was not on par with the lowest concentration of triacontanol.

The enzyme nitrate reductase catalyzes the reduction of nitrate to nitrite and is a rate limiting step in the nitrogen metabolism (Beevers and Hageman, 1969). It was observed that the activity of nitrate reductase increased significantly with the application of growth regulators.

The study by Prabhavathi (2005) revealed that nitrate reductase activity was maximum at 40 DAS in the genotype DWD-1 (local) but PusaNaubahar had maximum nitrate reductase activity at 60 DAS. The treatment lihocin (1000 ppm) recorded significantly higher nitrate reductase activity followed by miraculan (1000 ppm).

Similarly, Lawlor and Fock (1975) suggested that CCC induced increase in photosynthesis was associated with an increase in the enzyme activity and nucleic acid metabolism. CCC was also reported to increase cytokinin content in leaves leading to higher chlorophyll content (Skene, 1968). Possibly, CCC induced higher NRA and chlorophyll content may be due to the combination of various factors cited above, which in turn manifest the final yield. Similarly,
Sivakumar et al., (2002) also reported that foliar application of triacontanol @ 10 ppm increased the nitrate reductase activity in pearl millet.

\section{Crude gum (\%)}

The crude gum (\%) (Table 3) differed significantly due to spray of growth regulators during kharif and rabi seasons. The highest crude gum (kharif $31.97 \%$; rabi $29.69 \%$ ) was recorded by HG 365. Among the growth regulators, maximum crude gum (kharif 31.35 $\%$; rabi $29.19 \%$ ) was recorded by the application of CCC at $1500 \mathrm{ppm}$ which was on par with CCC 1000 ppm (kharif $31.22 \%$; rabi $29.07 \%$ ). TRIA resulted in the moderate value during both the seasons (kharif $30.85 \%$, rabi $28.73 \%$ ).

The lowest crude gum was observed by the spray of MC 500 ppm (kharif $29.25 \%$; rabi $27.26 \%$ ) which was on par with MC 1000 ppm (kharif $29.49 \%$; rabi $27.48 \%$ ). Crude gum content was in medium range in the seeds harvested from the plants which were treated by TRIA 1500 ppm during both kharif (30.85\%) and rabi (28.73\%) seasons. The control recorded a crude gum of $30.43 \%$ in kharif and $28.34 \%$ in rabi.

The content of crude gum in the seed governs the value of the guar produce since the gum is the product of export value. The cultivar HG 365 exhibited the highest gum content and among the growth regulators sprays, CCC at $1500 \mathrm{ppm}$ exhibited the highest gum content being the one having the bold sized seeds from significantly robust pods and clusters. The individual plant being capable of drawing more nutrients over an extended period of duration spent in building up of vegetative frame work and on the other hand prolonged reproductive period. Such a plant also exhibited better pod quality parameters and therefore was also able to produce seeds with a higher content of galactomannan. The sprays of CCC and triacontanol at $1500 \mathrm{ppm}$ were found on par with $1000 \mathrm{ppm}$, thus making the effect of additional amount of chemicals non-significant 
in increasing gum content of individual seeds. The highest effect in positive direction in increasing gum content was observed by the spray of CCC followed by triacontanol and mepiquat chloride. The highest concentration of traicontanol (1500 ppm) was found on par with the lowest concentration of CCC (500 ppm) but the same was not true between mepiquat chloride and triacontanol.

\section{Seed yield per plant $(g)$}

The seed yield per plant (Table 4) differed significantly due to spray of growth regulators during kharif and rabi seasons. The highest seed yield per plant (kharif $16.88 \mathrm{~g}$; rabi $16.04 \mathrm{~g}$ ) was recorded by HG 365 .

Among the growth regulators, maximum seed yield per plant (kharif $18.33 \mathrm{~g}$; rabi $17.42 \mathrm{~g}$ ) was recorded by the application of $\mathrm{CCC}$ at 1500 ppm which was on par with CCC 1000 ppm (kharif $18.05 \mathrm{~g}$; rabi $17.15 \mathrm{~g}$ ). The lowest seed yield per plant was observed by the spray of MC 500 ppm (kharif $14.58 \mathrm{~g}$; rabi $13.85 \mathrm{~g}$ ) which was on par with MC 1000 ppm (kharif $14.93 \mathrm{~g}$; rabi $14.18 \mathrm{~g}$ ).

TRIA 1500 ppm produced moderate quantities of seed per plant during both kharif $(16.94 \mathrm{~g})$ and rabi $(16.10 \mathrm{~g})$. The control recorded a seed yield per plant of $13.70 \mathrm{~g}$ in kharif and $13.01 \mathrm{~g}$ in rabi.

\section{References}

Beevers, L. and Hageman, R. H. 1969. Nitrate reduction in higher plants. Annual Review of Plant Physiology. 20: 495-522.
Haleh, A. and Ergin, D. 2010. The effect of salicylic acid and triacontanol on biomass production and imidaclopirid removal capacity by cyanobacteria. Commun. University of Ankara. 22 (1): 15-31.

Lawlor, D. W. and Fock, H. 1975. Photosynthesis and photorespiratory $\mathrm{CO}_{2}$ evolution of water stressed sunflower leaves. Planta. 126: 381- 87.

Panse, R. P. and Sukhatme, P. V. 1985. Statistical methods for agricultural workers.Indian Council of Agricultural Research. New Delhi.

Patel, J. C. and Singh, R. M. 1980. Effect of irrigation, mulching and bioregulators on the production of sunflowers. Indian Journal of Agronomy. 25: 122-28.

Prabhavathi, V.H. 2005. Effect of plant growth regulators, organics and nutrients on growth, physiology and yield in cluster bean (Cyamopsis tetragonoloba L. Taub.). M.Sc. (Agri.) Thesis. University of Agricultural Sciences Dharwad.

Prasanthi, and Krishna, G. 2012. Evaluation of high yielding varieties and package of practices in seed cluster bean.Anna data. 12: 20-22.

Skene, K. G. M. 1968. Increase in cytokinin in bleeding sap of Vitis vinifera L. after CCC treatment. Science. 159: 1477-78.

Undersander, D. J, Putnam, D. H, Kaminski, A. R, Kelling, K. A, Doll, J. D, Oplinger, E. S. and Gunsolus, J. L. 2006. Alternative Field Crops Manual, University of Wisconsin-Madison. PP: 34-38.

\section{How to cite this article:}

Tagore Naik, M., D. Srihari, A.V.D. Dorajeerao, K. Sasikala, K. Umakrishna and Suneetha, D.R.S. 2018. Effect of Plant Growth Regulators on Nitrate Reductase Activity in Seed Guar Varieties. Int.J.Curr.Microbiol.App.Sci. 7(11): 3096-3103. doi: https://doi.org/10.20546/ijcmas.2018.711.355 